\title{
Adjunctive Treatment with Low-Dose Polymyxin B Improves Operant Response Rates and Latency in Infant Rats with Haemophilus influenzae Type b Meningitis ${ }^{1}$
}

\author{
JUAN N. WALTERSPIEL AND WILLIAM F. VITULLI \\ University of South Alabama, Department of Pediatrics, College of Medicine, Department of Psychology, College \\ of Arts and Sciences, Mobile, Alabama 36617
}

\begin{abstract}
Polymyxin B given in conjunction with ampicillin protects infant rats against death from overwhelming Haemophilus influenzae type b infection. This study was undertaken to examine whether polymyxin B would mitigate the effects of brain damage caused by meningitis. Six- to 7-d-old Sprague-Dawley rats were infected subcutaneously into the nape with $10^{7}$ cfu Haemophilus influenzae type b strain Eagan. This dose consistently caused bacteremia $\left(1.2 \times 10^{5} \mathrm{cfu} / \mathrm{mL}\right)$ and meningitis $\left(0.5 \times 10^{5}\right.$ $\mathrm{cfu} / \mathrm{mL}$ ) in pilot studies. Twenty-four $\mathrm{h}$ after infection, all animals received intraperitoneal treatment consisting in either ampicillin alone $(400 \mathrm{mg} / \mathrm{kg} \times 4 \mathrm{q} 3 \mathrm{~h})$ repeated 12 $h$ later, $n=15$ or combined with polymyxin $B(0.1 \mathrm{mg} / \mathrm{kg} /$ dose) $n=16$. At age 2 mo, they were taken off ad libitum feeding and maintained at $80 \%$ of their wt. They were then conditioned to receive a food pellet by pressing a lever (continuous reinforcement). The next day, the time lapse between placement and pressing the lever for the first time was recorded (conditioned operant response or latency). Three wk later, the animals were put in the test chamber again and the time to press the lever (latency), as well as the time required to obtain 100 pellets (rate) were recorded. Animals who received polymyxin B had a significantly shorter reaction time; mean $34 \mathrm{~s}, \mathrm{SEM} \pm 5.7$ versus mean $88 \mathrm{~s}, \mathrm{SEM} \pm 26.3, P \leq 0.05$ and performed significantly faster in obtaining 100 pellets; mean $925 \mathrm{~s}, \mathrm{SEM} \pm \mathbf{7 2 . 1}$ versus mean $1283 \mathrm{~s}, \mathrm{SEM} \pm 126.3, p \leq 0.02$ (analysis of variance, Scheffé test). Adjunctive antiinflammatory therapy with low dose polymyxin $B$ appears to be a promising, inexpensive, and readily available mode of treatment for further study with eventual future application in the treatment of children with $H$. influenzae type b meningitis. (Pediatr Res 26: ;496-499, 1989)
\end{abstract}

Approximately 18000 pediatric cases of invasive infection with Haemophilus influenzae type b per year are recorded in the United States, and 900 to 1200 of these children die (1-3). Most children with $H$. influenzae type $\mathrm{b}$ meningitis are under $5 \mathrm{y}$ of age and approximately $75 \%$ are less than 18 mo of age. These younger children cannot be protected by currently approved vaccines (3-5). Permanent sequelae from meningitis have been observed in one-third to one-half of survivors in the past $(6,7)$

Received March 3, 1989; accepted July 7, 1989.

Juan N. Walterspiel, M.D., The University of Texas, 6431 Fannin JFB 1739, Houston, TX 77030 .

Presented in part as an oral presentation at the 28th ICAAC Meeting held in Los Angeles, CA (abstr 871). and more recently in $8 \%$ with possibly lowered IQ scores in $28 \%$ (8). However, many of the children learn to compensate for their diminished intellectual capacity with additional help at school and at home (9).

Further advances in antimicrobial agents are unlikely to improve outcome. Efforts have therefore focused on modulating the possibly deleterious inflammatory response by the host (10).

The lipid A portion of lipopolysaccharide or endotoxin is postulated to contribute to the stimulation of such inflammatory reactions in $H$. influenzae type $\mathrm{b}$ infection and the exposure of gram-negative organisms to antimicrobials causes an additional release of cell wall components $(11,12)$. This might explain the development of endotoxic shock that develops after the administration of antibiotics in some cases of severe $H$. influenzae type b infection (13).

Approaches have been explored to neutralize endotoxin with specific antibodies (14), to block endotoxin receptors with the lipid A precursor, lipid X $(15,16)$, and to use dexamethasone as nonspecific antiinflammatory agent $(10,17)$. Another way is to aim for the chemical neutralization of endotoxin. An agent that is approved for use in humans, polymyxin B, was successful in this respect by decreasing mortality in infant rats when given concomitantly at low doses with antimicrobial treatment in overwhelming infection due to $H$. influenzae type b (18). The next study was designed to address the question of whether such an approach could improve the neurofunctional outcome.

\section{MATERIALS AND METHODS}

Experimental infection and treatment. The pups were born to time pregnant, specific pathogen-free outbred albino SpragueDawley rats obtained from Charles River Breeding Laboratories, Wilmington, MA 01887 . The infection was set at age 6 to $7 \mathrm{~d}$ by injecting $\sim 10^{7} \mathrm{cfu}$ of $\mathrm{H}$. influenzae type b strain Eagan suspended in $0.1 \mathrm{~mL}$ PBS, $0.1 \%$ gelatin into the nape. The strain, kindly provided by Dr. T. J. Inzana (Baylor College of Medicine, Houston, TX), was grown to log phase and washed as previously described (18).

Its minimal inhibitory concentrations for ampicillin and polymyxin B were 0.1 and $0.003 \mu \mathrm{g} / \mathrm{mL}$, respectively. Ampicillin and polymyxin B did not have a synergistic effect in vitro (18). The theoretical possibility, that subinhibitory concentrations of polymyxin $\mathrm{B}$ might lead to a more rapid cidal action by ampicillin without influencing the mic of ampicillin was considered to be unlikely.

Twenty-four $\mathrm{h}$ after injection, all animals received $400 \mathrm{mg} /$ $\mathrm{kg}$ /dose ampicillin (polycillin-N, Bristol Meyers, Syracuse, NY) injections intraperitoneally. This dose was diluted in $0.15 \mathrm{~mL}$ of $\mathrm{NS}$ and given at a $3 \mathrm{~h} \times 4$ schedule which was repeated $12 \mathrm{~h}$ 
later. The adjunctive treatment group (about half of all animals in each litter, randomly selected before infection) received 0.1 $\mathrm{mg} / \mathrm{kg} /$ dose of polymyxin B sulfate (Aerosporin, BurroughsWellcome, Research Triangle Park, NC) mixed with ampicillin at the same dose, route, volume, and schedule described above. This dose of ampicillin is 120 times higher than the one of polymyxin B in relation to the mic's of the organism.

Control studies done before the experiment showed that the $10^{7} \mathrm{cfu}$ inoculum had produced bacteremia in all of six pups when cultured $24 \mathrm{~h}$ after inoculation (mean $1.2 \times 10^{5} \mathrm{cfu} / \mathrm{mL}$, median $1.6 \times 10^{5}$, range $0.3-2 \times 10^{5}$ ) and meningitis (mean 0.5 $\times 10^{5} \mathrm{cfu} / \mathrm{mL}$, median $1.3 \times 10^{5}$, range $\left.0.09-2 \times 10^{5}\right)$. The treatment schedule of $\mathrm{q} 3 \mathrm{~h} \times 4$ with and without polymyxin $\mathrm{B}$ added, sterilized blood, and CSF in another nine control animals cultured $48 \mathrm{~h}$ after treatment, confirmed previous experience with a similar schedule (18). A tenth animal was found to have one colony on a plate inoculated with undiluted CSF. Because of this one animal, we chose to repeat the treatment schedule after a 12-h interval in all study animals. The study animals that received the tested $10^{7} \mathrm{cfu}$ inoculum and treatment schedules were not cultured because the cardiac puncture and dissection to obtain CSF from the cisterna magna (under pentobarbitol) were considered too invasive and likely to introduce additional variables.

A noninfected control group was not included in the study, because it seemed difficult to rule out spread of subclinical infection within a litter containing infected pups. Furthermore, the competition of these healthy animals for maternal care could have influenced our results. A single litter was infected each month to allow for sufficient time to condition the individual animals as described below.

Training and later performance tests. At the time of weaning, the animals were put in individual cages marked with a random number. The individual color markers for the two treatment groups became undetectable after a period of 2 wk due to shedding and growth of new hairs. This allowed the blinding with respect to previous treatment of the one person who performed and recorded the training and memory performance tests (R.D.R.). When the animals reached 2 mo of age $\pm 1 \mathrm{wk}$, their previously free food supply (Rodent Blox, Wayne Feeds, Chicago, IL 60606) was controlled to reduce their wt to a steady level of $80 \%$. Animals were then placed in an operant conditioning cage (G 2150 Unit, Gerbrands Corp., Arlington, MA) with a provision to deliver food pellets (P.J. Noyes Corp., Lancaster, $\mathrm{NH}$ ) by pressing a lever. On the first day, the animals were placed in the cage for $40 \mathrm{~min}$ for habituation. This was in a room with a low noise level and dim light. On the second day, the animals were fed a food pellet via a remote control switch each time they came close to or touched the lever (continuous reinforcement). The magazine that delivered a food pellet produced an auditory click. A flash of light was also produced on the equipment control panel with each lever press. This was continued until each animal had learned to press the lever 100 times (acquisition). The time to obtain the first pellet (latency) was recorded for each subject $24 \mathrm{~h}$ later (conditioned operant response). Then $3 \mathrm{wk}$ later, the animals were individually placed in the same environment with automatic delivery of a food pellet whenever the lever was pressed. The time until the first press (latency) and the time to obtain 100 pellets (rate) was recorded. The animals' wt at the time of latency testing ranged from 149 to $352 \mathrm{~g}$ with a mean of 242.6 in the ampicillin/polymyxin B treated group and from 152 to $349 \mathrm{~g}$ with a mean of 212.2 in the group treated with ampicillin alone ( $p=0.24$ by two-tailed Student's $t$ test). Males and females were equally distributed in both treatment groups. A total of 31 animals underwent the operant conditioning with 16 of them having received ampicillin with polymyxin $B$ and 15 ampicillin alone. Seven animals receiving ampicillin and polymyxin $\mathrm{B}$ and five animals receiving ampicillin alone belonged to a pilot study. Data analyses were performed both including and excluding this latter group.

Statistical analysis. Analysis of variance was used with the factor treatment at two levels (ampicillin alone, ampicillin wtih adjunctive polymyxin B) for the three response measures; latency on acquisition and latency and rate on retesting. Pairwise comparisons between favor levels were conducted by the Scheffé test (19).

\section{RESULTS}

Animals treated with adjunctive, low dose polymyxin B had significantly shorter latencies and significantly faster rates of operant responding on retesting at three weeks compared to animals in the control group.

No significant difference was found for latency $24 \mathrm{~h}$ before training. The statistics describing the responses are given in Table 1. All observations from the retesting sessions that were made 3 wk after training are depicted in Figures 1 and 2. The $p$ values for the significant differences were $p \leq 0.012, p \leq 0.048$ for latency and $p \leq 0.02, p \leq 0.02$ for rate. The calculation of the last number includes observations from the pilot study.

\section{DISCUSSION}

Results of this study suggest that the effects of adjunctive lowdose treatment with the endotoxin neutralizing agent polymyxin $\mathrm{B}$ go beyond an increase in survival (18). The choice to investigate low-dose polymyxin B for meningitis, despite its poor penetration into the CSF, was based on speculations on findings in the

Table 1. Results and statistical analysis for three time variables using ANOVA and Scheffé test*

\begin{tabular}{|c|c|c|c|c|c|c|}
\hline & \multirow{2}{*}{\multicolumn{2}{|c|}{$\begin{array}{c}\text { Training session } \\
\text { Latency } 24 \mathrm{~h} \text { after training (s) }\end{array}$}} & \multicolumn{4}{|c|}{ Retesting session } \\
\hline & & & \multicolumn{2}{|c|}{ Latency at $3 \mathrm{wk}(\mathrm{s})$} & \multicolumn{2}{|c|}{ Rate at $3 \mathrm{wk}(\mathrm{s})$} \\
\hline & AMP & $\mathrm{AMP}+\mathrm{PMB}$ & AMP & $\mathrm{AMP}+\mathrm{PMB}$ & AMP & $\mathrm{AMP}+\mathrm{PMB}$ \\
\hline \multicolumn{7}{|l|}{$n=10 / 9$} \\
\hline Mean \pm SEM & $986.6 \pm 596.3$ & $107.0 \pm 32.6$ & $55.2 \pm 9.5$ & $25.0 \pm 4.3$ & $1101.7 \pm 87.3$ & $816.6 \pm 66.6$ \\
\hline \multirow[t]{2}{*}{ Range } & $15-6037$ & $24-326$ & $18-107$ & $11-43$ & $810-1593$ & $596-1078$ \\
\hline & \multicolumn{2}{|c|}{$p \geq 0.05$} & \multicolumn{2}{|c|}{$p \leq 0.012$} & \multicolumn{2}{|c|}{$p \leq 0.02$} \\
\hline \multicolumn{7}{|c|}{$\begin{array}{l}\text { All animals (incl. } \\
\text { pilot) } \\
n=15 / 16\end{array}$} \\
\hline $\begin{array}{l}\text { Mean } \pm \text { SEM } \\
\text { Range }\end{array}$ & $\begin{array}{c}739.7 \pm 402.2 \\
15-6037\end{array}$ & $\begin{array}{c}786.6 \pm 655.5 \dagger \\
24-9300\end{array}$ & $\begin{array}{c}88.3 \pm 26.3 \\
18-435\end{array}$ & $\begin{array}{c}34.6 \pm 5.7 \\
11-91\end{array}$ & $\begin{array}{c}1283.2 \pm 126.3 \ddagger \\
810-2785\end{array}$ & $\begin{array}{c}925.8 \pm 72.1 \neq \\
596-2550\end{array}$ \\
\hline Range & \multicolumn{2}{|c|}{$p \geq 0.05$} & \multicolumn{2}{|c|}{$p \leq 0.048$} & \multicolumn{2}{|c|}{$p \leq 0.02$} \\
\hline
\end{tabular}

* AMP, ampicillin; $\mathrm{PMB}$, polymyxin $\mathrm{B}$.

$\dagger$ Two observations in the pilot group (polymyxin B) were not available.

$\ddagger$ One high outlier from each treatment group was excluded. 


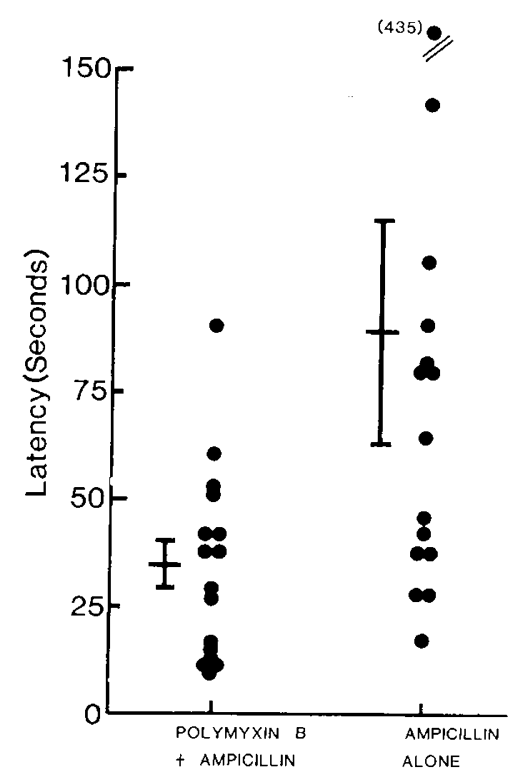

Fig. 1. Times (s) it took animals in the two groups to press the lever the first time during retest session (latency). I, mean and SEM (all observations).

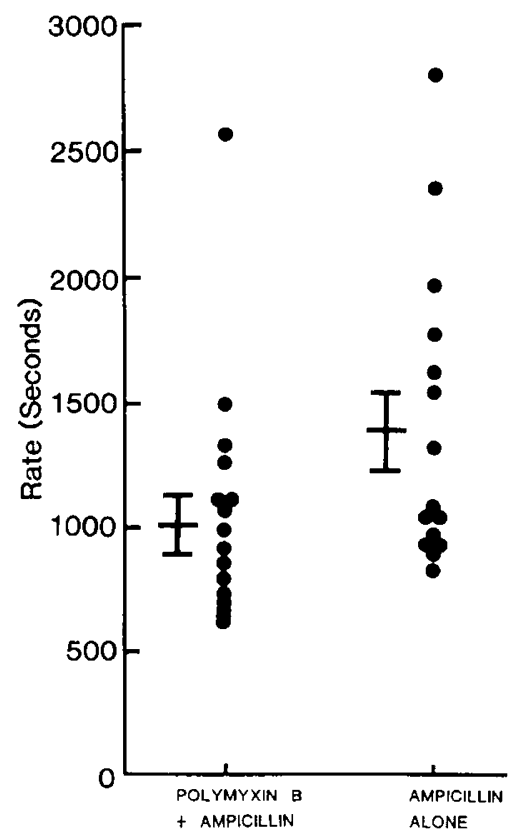

Fig. 2. Times (s) it took animals in the two groups to obtain 100 pellets by pressing the lever during retest session (rate). I, mean and SEM (all observations).

literature suggesting that part of the pathophysiologic process in bacterial meningitis takes place at the vascular level (20-23). Furthermore, we believed that a high and CSF-penetrating dose of polymyxin B $(1.5 \mathrm{mg} / \mathrm{kg})$, which has been shown to decrease brain edema and endotoxin activity in rabbits infected with Escherichia coli (24), might expose humans to unwanted toxicity (25).

Endotoxin is known to exert a direct detrimental effect on endothelial cells (26-29), which also is mediated through neutrophils (30) and oxidized low-density lipoprotein-endotoxin complexes in humans (31). It causes platelet reactions that in turn damage the endothelium directly (32-36), or the platelets might fail their normal function to maintain endothelial integrity (37).

Numerous studies have documented the mitigating effects of polymyxin $\mathrm{B}$ on a wide variety of in vitro and in vivo reactions to endotoxin. These are thought to be due to neutralization by binding of polymyxin B to endotoxin molecules. Not all endotoxins and endotoxin preparations although are equally susceptible. Membrane material with endotoxin activity released from $H$. influenzae type B strain Eagan was shown to be neutralized when tested with a chromogenic Limulus lysate assay (18). Less well-characterized effects of polymyxin B on cell membranes and perturbation of signals leading to protein kinase-C activation (38) are potential alternative explanations for the biologic effects of polymyxin $B$.

Most of the relevant studies describing neutralization are cited in the discussions by Flynn (39) and Walterspiel (18). The literature seems more notable for the paucity of reports describing failure with polymyxin $\mathrm{B}$ under various experimental conditions than the many descriptions of its mitigating effects. We did not aim at exploring a specific mechanism of action, but to detect an overall beneficial effect on an observable behavioral function in rats.

The infant rat meningitis model was chosen, because it most closely mimics the histopathology seen in humans (40-42) with documented deficiencies in conditioned behavior of infected animals $(40,43)$. Lower rates of operant behavior under schedules of continuous reinforcement were found among rats infected at $5 \mathrm{~d}$ of age when this model was first described (40). Reinforcement by water was used in that study as compared to the food reinforcement in our study. In another study, active and passive avoidance tasks showed significant impairment in rats inoculated at $6 \mathrm{~d}$ of age with a capsulated strain of $H$. influenzae, compared to those pups who were given a nonvirulent, uncapsulated strain (43). The $H$. influenzae infected group also showed increased locomotor activity during habituation to the conditioning chamber (43).

The present observation suggests that adjunctive treatment with polymyxin B in Sprague-Dawley pups resulted in decreased latency and increased rate of operant responding, as adults. These differences were seen during retesting $3 \mathrm{wk}$ after training and can be interpreted as improved learning during the first test for latency and/or better recall. Our model studied the effect of polymyxin B on one rat behavior and maintenance only. Future studies comparing a wider set of observable behaviors might point toward areas of maximum, no, or even detrimental effects of combined therapy.

Adjunctive antiinflammatory therapy with low dose polymyxin $B$ appears to be a promising, inexpensive, and readily available mode of treatment. It might be suitable for more detailed study not only with the goal to decrease mortality from gram-negative sepsis, but also to diminish neurobehavioral sequelae in children with $H$. influenzae type b meningitis.

Acknowledgment. The authors thank Robert D. Ronnlund for expert technical assistance and patience observing the animals and Mae Jean Reeves for typing the manuscript.

\section{REFERENCES}

1. Redmond SR, Pichichero ME 1984 An epidemiologic study with special reference to day care centers. JAMA 252:2581-2584

2. Cochi SL, Broome CV, Hightower AW 1985 Immunization of US children with Haemophilus influenzae type b polysaccharide vaccine. JAMA 253:521529

3. Eskola J, Peltola H, Takala K, Kayhty H, Hakulinen M, Karanko V, Kela E, Rekola P, Ronnberg PR, Samuelson JS, Gordon LK, Makela PH 1987 Efficacy of Haemophilus influenzae type b polysaccharide-diphtheria toxoid conjugate vaccine in infancy. $N$ Engl $J$ Med 317:717-722

4. Immunization Practices Advisory Committee (ACIP) 1988 Update: prevention of Haemophilus influenzae type b disease. MMWR 37:13-16

5. Mortimer EA 1988 Efficacy of Haemophilus b polysaccharide vaccine: An enigma. JAMA 260:1454-1455

6. Sell SHW, Merrill RE, Doyne EO, Zimsky EP 1972 Long-term sequelae of Haemophilus influenzae meningitis. Pediatrics 49:206-211

7. Sell SHW, Webb WW, Pate JE, Doyne EO 1972 Psychological sequelae to bacterial meningitis: Two controlled studies. Pediatrics 49:212-217

8. Feigin RD, Stechenberg BW, Chang MJ, Dunkle LM, Wong ML, Palkes $\mathrm{H}$, Dodge PR, Davis H 1976 Prospective evaluation of treatment of Haemophilus influenzae meningitis. J Pediatr 88:542-548

9. Feldman HM, Michaels RH 1988 Academic achievement in children ten to 
12 years after Haemophilus influenzae meningitis. Pediatrics 81:339-344

10. Lebel MH, Freij BJ, Syrogiannopoulos GA, Chrane DF, Hoyt MJ, Stewart SM, Kennard BD, Olsen KD, McCracken GH Jr 1988 Dexamethasone therapy for bacterial meningitis. N Engl J Med 319:964-971

11. Walterspiel JN 1988 Differences in endotoxin release from Escherichia coli, Haemophilus influenzae type $\mathrm{b}$ and Pseudomonas aeruginosa by third generation cephalosporins, aminoglycosides and ciprofloxacin at MIC and MIC $\times 8$ concentrations. Pediatr Res $23: 385 \mathrm{~A}$

12. Shenep JL, Mogan KA 1984 Kinetics of endotoxin release during antibiotic therapy for experimental gram-negative bacterial sepsis. J Infect Dis 150:380388

13. Sowell MK, Jacobs RF, Fiser DH, Moss MM 1988 Septic shock in children. Pediatr Res 23:236A

14. Marks MI, Ziegler EJ, Douglas H, Corbeil LB, Braude AI 1982 Induction of immunity against lethal Haemophilus influenzae type b infection by Escherichia coli core lipopolysaccharide. J Clin Invest 69:742-749

15. Golenbock DT, Leggett JE, Rasmussen P, Craig WA, Raetz CRH, Proctor RA 1988 Lipid X protects mice against fatal Escherichia coli infection. Infect Immun 56:779-784

16. Proctor RA, Will JA, Burhop KE, Raetz CRH 1986 Protection of mice against lethal endotoxemia by a lipid A precursor. Infect Immun 52:905-907

17. Syrogiannopoulos GA, Olsen KD, Reisch JS, McCracken GH 1987 Dexamethasone in the treatment of experimental Haemophilus influenzae type $b$ meningitis. J Infect Dis 155:213-219

18. Walterspiel JN, Kaplan SL, Mason EO 1986 Protective effect of subinhibitory polymyxin $\mathrm{B}$ alone and in combination with ampicillin for overwhelming Haemophilus influenzae type $\mathrm{b}$ infection in the infant rat: Evidence for in vivo and in vitro release of free endotoxin after ampicillin treatment. Pediatr Res 20:237-241

19. Scheffe $H 1953 \mathrm{~A}$ method for judging all contrasts in the analysis of variance. Biometrika 40:87-104

20. Wertham F 1931 The cerebral lesions in purulent meningitis. Arch Neurol Psychiat 26:549-582

21. Gado M, Axley J, Appleton DB, Prensky AL 1974 Angiography in the acute and post-treatment phases of Haemophilus influenzae meningitis. Radiology $110: 439-444$

22. James AE Jr, Hodges FJ III, Jordan CE, Mathews EH, Heller R Jr 1972 Angiography and cisternography in acute meningitis due to Haemophilis influenzae. Radiology 103:601-605

23. Raimondi AJ, DiRocco C 1979 The physiopathogenetic basis for angiographic diagnosis of bacterial infections of the brain and its covering in children. ILeptomeningitis. Childs Brain 5:1-13

24. Täuber MG, Shibl AM, Hackbarth CJ, Larrick JW, Sande MA 1987 Antibiotic therapy, endotoxin concentration in cerebrospinal fluid, and brain edema in experimental Escherichia coli meningitis in rabbits. J Infect Dis 156:456462

25. Goodman LS, Gilman A 1970 The Pharmacological Basis of Therapeutics Fourth Edition, The Macmillan Company, New York, pp 1287-1290 covering in children. I-Leptomeningitis. Childs Brain 5:1-13

26. Gerrity RG, Caplan BA, Richardson M, Cade JF, Hirsh J, Schwartz CJ 1975 Endotoxin-induced endothelial injury and repair. I. Endothelial cell turnover in the aorta of the rabbit. Exp Mol Pathol 23:379-385

27. Gerrity RG, Richardson M, Caplan BA, Cade JF, Hirsh J, Schwartz CJ 1976 Endotoxin-induced vascular endothelial injury and repair. II. Focal injury, en face morphology, $\left[{ }^{3} \mathrm{H}\right]$ thymidine uptake and circulating endothelial cells in the dog. Exp Mol Pathol 24:59-69

28. Reidy MA, Schwartz SM 1983 Endothelial injury and regeneration. IV. Endotoxin: nondenuding injury to aortic endothelium. Lab Invest 48:25-34

29. Libby P, Ordovas JM, Auger KR, Robbins AH, Birinyi LK, Dinarello CA 1986 Endotoxin and tumor necrosis factor induce interleukin-1 gene expression in adult human vascular endothelial cells. Am J Pathol 124:179-185

30. Smedly LA, Tonnesen MG, Sandhaus RA, Haslett C, Guthrie LA, Johnston RB Jr, Henson PM, Worthen GS 1986 Neutrophil-mediated injury to endothelial cells. Enhancement by endotoxin and essential role of neutrophil elastase. J Clin Invest 77:1233-1243

31. Morel DW, DiCorleto PE, Chisolm GM 1986 Modulation of endotoxininduced endothelial cell toxicity by low density lipoprotein. Lab Invest $55: 419-426$

32. Semeraro N, Colucci M, Vermylen J 1979 Complement-dependent and complement-independent interactions of bacterial lipopolysaccharides and mucopeptides with rabbit and human platelets. Thromb Haemost 41:392-406

33. Ginsberg MH, Henson PM 1978 Enhancement of platelet response to immune complexes and IgG aggregates by lipid A-rich bacterial lipopolysaccharides. J Exp Med 147:207-218

34. Walker RI, Fletcher JR 1980 Evidence that injury to platelets can contribute to the diversity of host responses to endotoxin. In: Agarwal MK (ed) Bacterial Endotoxins and Host Response. Elsevier/North-Holland Biomedical Press, New York, pp 327-338

35. Morrison DC, Oades ZG, DiPietro D 1980 Endotoxin induced calciumdependent platelet secretion-implications for generalized membrane perturbations. In Agarwal MK (ed), Bacterial Endotoxins and Host Response. Elsevier/North-Holland Biomedical Press, New York, pp 311-325

36. Hawiger J, Hawiger A, Steckley S, Timmons S, Cheng C 1977 Membrane changes in human platelets induced by lipopolysaccharide endotoxin. $\mathrm{Br} \mathrm{J}$ Haematol 35:285-299

37. Kitchens CS, Weiss L, 1975 Ultrastructural changes of endothelium-associated with thrombocytopenia. Blood 46:567-578

38. Nel AE, Wooten MW, Goldschmidt-Clermont PJ, Miller PJ, Stevenson HC Galbraith RM 1985 Polymyxin B causes coordinate inhibitions of phorbol ester-induced C-kinase activity and proliferation of B lymphocytes. Biochem Biophys Res Commun 128:1364-1372

39. Flynn PM, Shenep JL, Stokes DC, Fairclough D, Hildner WK 1987 Polymyxin B moderates acidosis and hypotension in established, experimental gramnegative septicemia. J Infect Dis 156:706-712

40. Smith AL, Smith DH, Avrill DR Jr, Marino J, Moxon ER 1973 Production of Haemophilus influenzae $\mathrm{b}$ meningitis in infant rats by intraperitoneal inoculation. Infect Immun 8:278-290

41. Moxon ER, Smith AL, Averill DR, Smith DH 1974 Haemophilus influenzae meningitis in infant rats after intranasal inoculation. J Infect Dis 129:154162

42. Merchant RE, Willard JE, Daum RS 1981 Ultrastructural histopathology of experimental Haemophilus influenzae type $\mathrm{b}$ meningitis in the infant rat. $\mathbf{J}$ Submicrosc Cytol 13:501-514

43. Konkol RJ, Chapman L, Breese GR, Collier AM, Kilts C, Finley C, Vogel RR, Mailman RB, Bendeich EG 1987 Haemophilus influenzae meningitis in the rat: Behavioral ,electrophysiological, and biochemical consequences. Ann Neurol 21:353-360 